\title{
Proposed Nomenclature for Human Butyrylcholinesterase Genetic Variants Identified by DNA Sequencing
}

\author{
Bert N. La Du, ${ }^{1}$ Cynthia F. Bartels, ${ }^{1}$ Christine P. Nogueira, ${ }^{1}$ \\ Martine Arpagaus, ${ }^{1,2}$ and Oksana Lockridge ${ }^{1,3}$
}

Received November 20, 1989; accepted August 3, 1990

KEY WORDS: butyrylcholinesterase; serum cholinesterase; pseudocholinesterase; anionic site; atypical; silent; fluoride resistant; $K$ variant; succinylcholine apnea.

\section{SUMMARY}

1. New information identifying nucleotide alterations of human butyrylcholinesterase allows the use of more specific nomenclature for the variants commonly known as atypical, fluoride, silent, and $\mathrm{K}$ variant.

2. In addition to suggesting a system of trivial names and abbreviations, we provide a list of formal names that follow the guidelines of the Committee for Human Gene Nomenclature.

3. It is suggested that formal names be included in publications whenever possible.

\section{INTRODUCTION}

There is a need for a systematic nomenclature that reflects new knowledge of the structure of human butyrylcholinesterase (BCHE, gene; $\mathrm{BChE}$, protein). Specific nucleotide and amino acid alterations in certain genetic variants have recently been identified (McGuire et al., 1989; Nogueira et al., 1990). Our proposal for a new nomenclature recognizes the need to relate the names contained in over 30

\footnotetext{
${ }_{1}^{1}$ Pharmacology Department, Medical Science I, M6322, University of Michigan Medical School, Ann Arbor, Michigan 48109-0626.

${ }^{2}$ Present address: INRA, Génétique Moléculaire des Invertébrés, 123 Blvd. Francis Meilland, 06606 Antibes Cedex, France.

${ }^{3}$ Present address: University of Nebraska Medical Center, Eppley Institute, 600 South 42nd Street, Omaha, Nebraska 68198-6805.
} 
years of literature to the new information. Therefore, we propose to use a set of trivial names and trivial abbreviations that reflect the old established names, and in addition, we provide a list of formal names that follow the guidelines of the Committee for Human Gene Nomenclature (Shows et al., 1987; P. J. McAlpine, personal communication).

\section{RECOGNIZED GENETIC VARIANTS}

Nine genetic variants of human serum butyrylcholinesterase are listed in Table I. In most cases variants were recognized after patients responded abnormally to the muscle relaxant succinylcholine. For example, a person who is homozygous for the atypical form of serum butytylcholinesterase experiences $30 \mathrm{~min}$ to $2 \mathrm{hr}$ of muscle paralysis rather than the intended 2 to 3 min after receiving a single dose of succinylcholine (Kalow, 1962; Viby-Mogensen, 1983). Variants with increased activity are resistant to succinylcholine and may require two to three doses to achieve the desired state of paralysis. To date succinylcholine is the only drug known to cause abnormal clinical effects in people with rare butyrylcholinesterase genetic variants. Two other drugs in the testing stages, bambuterol, a prodrug for the bronchodilator drug terbutaline used to treat asthma (Tunek and Svensson, 1988), and mivacurium chloride, a new muscle relaxant (Savarese et al., 1988), also seem to have variable effects that correlate with BCHE genotype. Aspirin, cocaine, and heroin (Lockridge, 1990) are hydrolyzed by butyrylcholinesterase, but clinical studies have not been carried out to determine whether abnormal responses to these drugs correlate with a rare

Table I. Genetic Variants of Human Serum Butyrylcholinesterase

\begin{tabular}{|c|c|c|}
\hline Common name & $\begin{array}{c}\text { Frequency of homozygote } \\
\text { phenotype }\end{array}$ & Reference \\
\hline $\begin{array}{l}\text { Normal activity } \\
\text { Usual }\end{array}$ & $96: 100$ & Whittaker (1986) \\
\hline $\begin{array}{l}\text { Reduced activity } \\
\text { Atypical }\end{array}$ & $1: 3500$ & $\begin{array}{l}\text { Kalow and Staron (1957) } \\
\text { Kalow and Gunn (1959) }\end{array}$ \\
\hline Silent & $1: 100,000$ & Liddell et al. $(1962)$ \\
\hline Fluoride & $1: 150,000$ & Harris and Whittaker (1961) \\
\hline Quantitative Variant $\mathrm{J}$ & $1: 150,000$ & $\begin{array}{l}\text { Garry et al. (1976) } \\
\text { Evans and Wardell (1984) }\end{array}$ \\
\hline Quantitative Variant K & $1: 100$ & $\begin{array}{l}\text { Rubinstein et al. (1978) } \\
\text { Whittaker and Britten (1988) }\end{array}$ \\
\hline Quantitative Variant $\mathbf{H}$ & 2 families & Whittaker and Britten (1987) \\
\hline Newfoundland & 1 family & Simpson and Elliott (1981) \\
\hline $\begin{array}{l}\text { Increased activity } \\
\text { Cynthiana Variant }\end{array}$ & 4 families & $\begin{array}{l}\text { Neitlich (1966) } \\
\text { Yoshida and Motulsky (1969) } \\
\text { Delbruck and Henkel (1979) } \\
\text { Krause } \text { et al. (1988) }\end{array}$ \\
\hline
\end{tabular}


BCHE genetic variant. Whittaker (1986) has reviewed the biochemical properties of the rare variants. Table I does not include the C5 variant formerly attributed to a second $\mathrm{BCHE}$ locus because this second locus codes for a noncholinesterase protein (Masson et al., 1990). The C5 variant is not important to the anesthetist.

\section{PHENOTYPING}

In our laboratory butyrylcholinesterase activity is usually measured by the method of Kalow and Lindsay (1955) using benzoylcholine as substrate. Dibucaine number is percentage inhibition of activity in the presence of $10 \mu M$ dibucaine (Kalow and Genest, 1957). Fluoride number is percentage inhibition of activity in the presence of $50 \mu M$ sodium fluoride (Harris and Whittaker, 1961). $\mathrm{RO} 2$ number is percentage inhibition after incubation of the plasma or serum in $10^{-8} M$ RO2-0683 for $1 \mathrm{hr}$ prior to the addition of substrate (Evans and Wardell, 1984). RO2-0683 is the dimethylcarbamate of (2-hydroxy-5-phenylbenzyl)trimethyl ammonium.

The phenotyping method introduced by Kalow and Genest (1957), based on dibucaine number, is an excellent and reliable method for determining whether a person has atypical cholinesterase. The atypical allele can be detected in homozygotes as well as in heterozygotes. This is a very special feature of atypical $\mathrm{BChE}$, since most of the other variants cannot be identified when they occur in combination with the usual allele. It is therefore difficult or impossible to tell by phenotyping tests whether a person is a carrier of the silent, fluoride, $\mathrm{H}, \mathrm{J}, \mathrm{K}$, or Newfoundland variant unless the family also has the atypical variant and enough members of a family are tested to determine the pattern of inheritance.

\section{GENOTYPING}

The new methods of gene amplification by the polymerase chain reaction (PCR) followed by DNA sequencing (McGuire et al., 1989; Nogueira et al., 1990) and PCR followed by probing with a biotinylated oligonucleotide (La Du et al.,

Table II. Nomenclature for Homozygous Forms of Human Butyrylcholinesterase Variants ${ }^{a}$

\begin{tabular}{|c|c|c|c|c|}
\hline $\begin{array}{l}\text { Common } \\
\text { name }\end{array}$ & $\begin{array}{l}\text { Phenotypic } \\
\text { description }\end{array}$ & $\begin{array}{l}\text { Amino acid } \\
\text { alteration }\end{array}$ & $\begin{array}{c}\text { DNA } \\
\text { alteration }\end{array}$ & $\begin{array}{c}\text { Formal } \\
\text { name for genotype }\end{array}$ \\
\hline Usual & Normal & None & None & $B C H E$ \\
\hline Atypical & $\begin{array}{r}\text { Dibucaine } \\
\text { resistant }\end{array}$ & 70 Asp $\rightarrow$ Gly & nt 209 (GAT to GGT) & $B C H E^{*} 70 G$ \\
\hline Silent-1 & $\begin{array}{l}\text { Silent, no } \\
\text { activity }\end{array}$ & 117 Gly $\rightarrow$ Frameshift & nt 351 (GGT to GGAG) & $B C H E^{*} F S 117$ \\
\hline Fluoride-1 & $\begin{array}{l}\text { Fluoride } \\
\text { resistant }\end{array}$ & $243 \mathrm{Thr} \rightarrow$ Met & nt 728 (ACG to ATG) & $B C H E^{*} 243 M$ \\
\hline Fluoride-2 & $\begin{array}{l}\text { Fluoride } \\
\text { resistant }\end{array}$ & 390 Gly $\rightarrow$ Val & nt 1169 (GGT to GTT) & $B C H E^{*} 390 V$ \\
\hline $\mathrm{K}$ variant & $\begin{array}{l}\text { K poly- } \\
\text { morphism }\end{array}$ & $539 \mathrm{Ala} \rightarrow \mathrm{Thr}$ & nt 1615 (GCA to $\mathrm{ACA})$ & $B C H E^{*} 539 T$ \\
\hline
\end{tabular}

amino acid 1 as well as codon 1 is the $\mathrm{N}$ terminal of the mature protein. 


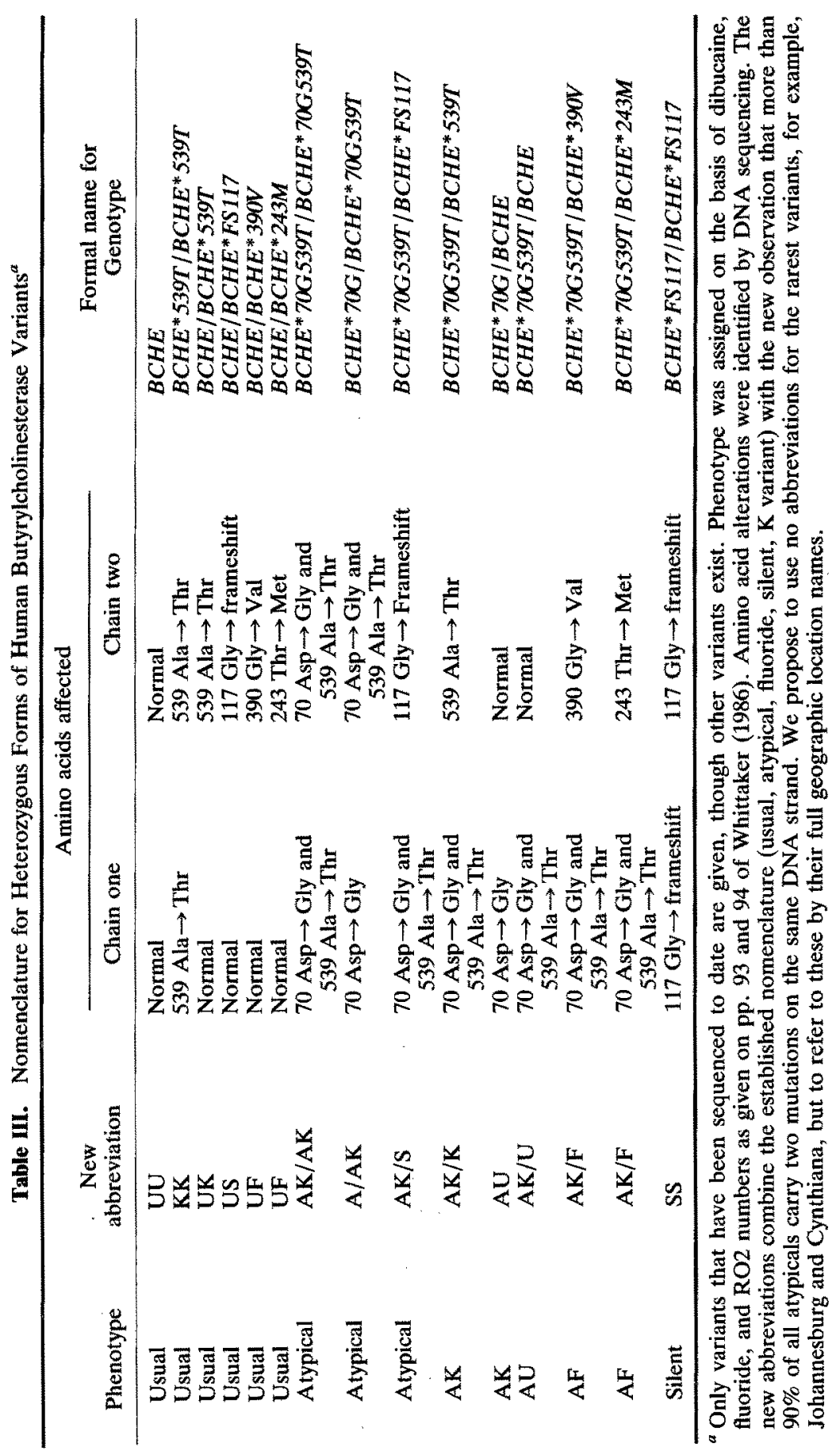


1990) have allowed identification of the nucleotide alterations in the variants of BCHE. DNA sequencing overcomes the limitations of phenotyping, because all variants can be precisely identified. Furthermore the new methods discriminate among similar phenotypes, such as fluoride-1 and fluoride-2. Tables II and III list the variants identified in our laboratory by DNA sequencing. Figures showing the location of nucleotide and amino acid substitutions within the complete sequence of human BChE have been published (Arpagaus et al., 1990; Lockridge, 1990). A limitation of DNA sequencing is that it is slow compared to phenotyping, requiring 1 week rather than $30 \mathrm{~min}$ to analyze one person.

\section{ATYPICAL}

All atypicals sequenced to date have a substitution at nucleotide 209, changing $A$ to $G$ and changing codon 70 from aspartic acid to glycine (McGuire et al., 1989). The number of unrelated atypical alleles we have sequenced is 20 . Atypical BChE has the kinetic properties of an enzyme that has a deficient anionic site. Atypical $\mathrm{BChE}$ has a reduced affinity for neutral substrates and a normal turnover number, $k_{\text {cat }}$ (Lockridge and La Du 1978). Therefore, Asp 70 appears to be an essential component of the anionic site.

A second substitution was found in greater than $90 \%$ of atypical genes. The second substitution was at nucleotide 1615 , where $G$ was replaced by $A$ and codon 539 was changed from alanine to threonine. Since some atypicals lack this second substitution we conclude that the atypical phenotype is due to the substitution of Asp 70 by Gly (McGuire et al., 1989). The 539 Ala $\rightarrow$ Thr mutation represents the $\mathrm{K}$ variant. Thus, a single $\mathrm{BCHE}$ chromosomal strand may carry two mutations: the mutation responsible for the atypical phenotype and a mutation responsible for the $\mathrm{K}$ variant phenotype. This linkage disequilibrium would be expected if a founder were responsible for the atypical genes, and his atypical mutation occurred on a chromosomal strand carrying the $K$ mutation. The disequilibrium with the $\mathrm{K}$ variant mutation may well explain why there are about one-third less atypical than usual BChE molecules per $\mathrm{ml}$ of serum (Eckerson et al., 1983).

\section{K VARIANT}

The $\mathrm{K}$ variant, named in honor of Werner Kalow, is associated with a $33 \%$ reduction in serum $\mathrm{BChE}$ activity (Rubinstein et al., 1978). By sequencing the DNA of family members and by pedigree analysis, we found that the $K$ phenotype was associated with a single nucleotide substitution at nucleotide 1615 , which changed codon 539 from alanine to threonine (Bartels et al., 1989). Our conclusion that this substitution explained the $K$ variant was supported by the observation that the frequency of the $539 \mathrm{Ala} \rightarrow \mathrm{Thr}$ mutation was equivalent to the $1 \%$ frequency of the homozygote $\mathrm{K}$ variant (Evans and Wardell, 1984; Whittaker and Britten, 1985). Though the $K$ variant is the most common 
mutation of $\mathrm{BChE}$, its clinical importance has been noted only when it is present in association with atypical $\mathrm{BChE}$.

\section{FLUORIDE}

The fluoride phenotype is resistant to the inhibitor NaF. Two mutations causing the fluoride phenotype have been found so far. One family had a substitution at nucleotide 728 of $\mathrm{C}$ to $\mathrm{G}$, changing codon 243 from Thr to Met, while three families had a substitution at nucleotide 1169 of $\mathrm{G}$ to $\mathrm{T}$, changing codon 390 from Gly to Val. The first fluoride mutation identified by DNA sequencing is fluoride- 1 , the second is fluoride- 2 , etc.

\section{SILENT}

The silent phenotype is characterized by zero BChE activity or very low activity, less than $2 \%$ of normal (Rubinstein et al., 1970). We have identified one type of silent mutation called silent-1 or silent-Ann Arbor (Nogueira et al., 1990). The mutation in Table II was found in two unrelated families, one ItalianAmerican and one Persian. This is a complex mutation in which the $T$ at nucleotide 351 was replaced by two nucleotides, AG. The frameshift caused a stop codon to appear at codon 129 so that protein synthesis was prematurely terminated. Only a truncated $\mathrm{BChE}$, about $22 \%$ of the length of the usual enzyme, could be produced. It lacked the active site serine at position 198 and therefore had no activity. The serum from this silent phenotype did not cross-react with antibody to human serum $\mathrm{BChE}$ and had zero activity with benzoylcholine and alpha-naphthylacetate. Another serum with the silent phenotype also had zero $\mathrm{BChE}$ activity and no cross-reactive material but did not contain the above mutation. Therefore a silent- 2 is likely to exist.

\section{NOMENCLATURE}

Trivial Names A modification of the trivial names for the genetic variants has already been suggested above. A number following the trivial name, for example, fluoride-1, fluoride-2, can be used to indicate that the fluoride phenotype includes several different nucleotide alterations (Table II). Following a practice established for the hemoglobin variants, a geographic name can be used as a trivial name. The geographic name can be appended to an already existing trivial name, as in silent-Ann Arbor, or can be used alone as in variants Newfoundland, Cynthiana, and Johannesburg.

In daily laboratory work it is our practice to use the simplest names possible. A system of two-letter abbreviations is well established but fails to describe the fact that most atypicals contain two mutations. Therefore, we propose a system of two-, three-, and four-letter abbreviations in Table III. A two-letter abbreviation 
is used for a genotype having one mutation per DNA strand, for example, SS for homozygous silent. Three- and four-letter abbreviations are used when one or both alleles contain a double mutation. The double mutation on a single DNA strand of atypicals is represented by two letters, AK. If only one strand has a double mutation while the second strand has a single mutation, the abbreviation contains three letters, for example, AK/K. The genotype abbreviation for a double mutation on both alleles is $\mathrm{AK} / \mathrm{AK}$ with a slash separating the two alleles. This system of trivial abbreviations does not distinguish between fluoride- 1 and fluoride-2, both being refferred to as F, but numbers could be added if this distinction becomes necessary.

Formal Names. The Human Gene Mapping Nomenclature Committee has designated $B C H E$ as the gene symbol for butyrylcholinesterase (P. J. McAlpine, personal communication). $B C H E$ now replaces $C H E 1$, the former symbol. $B C H E L 1$ and $B C H E L 2$ are the butyrylcholinesterase-like sites to which the cDNA probe hybridizes (Soreq et al., 1987; Zakut et al., 1989). Italics represent genotype, while standard type represents phenotype. An asterisk separates the symbols for gene and allele, and the single-letter amino acid symbol is used to identify mutations (Shows et al., 1987). In the example $B C H E^{*} 70 G$, the 70th amino acid from the $\mathrm{N}$ terminal of the mature protein has a substitution of glycine for aspartate (70 Asp $\rightarrow$ Gly). A slash separates alleles and indicates chromosome homologues. Frameshift is indicated by FS. In the example $B C H E^{*} 70 G 539 T /$ $B C H E^{*} F 117$, one allele has a double mutation $(70 \mathrm{Asp} \rightarrow$ Gly and $539 \mathrm{Ala} \rightarrow$ Thr), while the second allele has a frameshift mutation at codon 117 . See Table III.

The gene symbol for human acetylcholinesterase has been designated $A C H E$. Drosophila, nematode, and mouse geneticists use Ace as the symbol for the ACHE gene. However, Ace cannot be used for human acetylcholinesterase because all letters are not capitalized. $A C E$ is not available as a gene symbol for human acetylcholinesterase because it has been assigned to a different human gene.

The gene symbol for the C5 phenotype will remain CHE2 until the C5 phenotype is better understood (P. J. McAlpine, personal communication).

\section{ONE FUNCTIONAL BUTYRLCHOLINESTERASE GENE}

There is general agreement that the rare genetic variants, atypical, fluoride, and silent, are allelic with the usual form of BChE. Linkage analysis showed that BChE was closely linked to human transferrin (Robson et al., 1966; Sparkes et al., 1984). When Yang et al., (1984) mapped transferrin to human chromosome 3 in the long arm q21-25, it was clear that BCHE also mapped in this region. The in situ hybridization studies of Soreq et al., (1987) with a human BCHE cDNA probe confirmed that chromosome $3 \mathrm{q} 21-26$ was the location of a human BCHE gene.

The idea that two loci may code for human BChE originated in the work of Harris et al., (1963), who reported that an extra, slow-migrating component, C5, 
was inherited independently of the atypical variant. It was unclear whether C5 represented a second $\mathrm{BCHE}$ gene or represented a noncholinesterase protein. It became common to refer to two $\mathrm{BCHE}$ loci and to lose sight of the possibility that the second locus could be coding for a modifying protein that was not $\mathrm{BChE}$, although Scott and Powers (1974) concluded that C5 was a hybrid between BChE and a second protein, whose identity was unknown. The chromosomal location of C5, whose gene symbol is CHE2, was tentatively identified by Lovrien et al. (1978) as chromosome 16 based on a weak linkage with $\mathrm{Hp}$ and a lod score of 2.3. Marazita et al. (1989) also showed a weak linkage of CHE2 and haptoglobin on chromosome 16, with a lod score of 2.5. A lod score less than 3.0 is considered statistically insignificant and therefore both Lovrien et al. (1978) and Marazita et al. (1989) were cautious in assigning CHE2 to chromosome 16. A much stronger lod score of 4.2 was obtained by Eiberg et al. (1989) for the linkage between $\gamma$-crystallin gene cluster, CRYG, and CHE2, thus mapping CHE2 to chromosome 2 bands q33-q35. Eiberg's result that CHE2 mapped to chromosome 2 did not, by itself, rule out the possibility that $\mathrm{CHE} 2$ represented a second $\mathrm{BCHE}$ locus. This interpretation can, however, be made from the data of Soreq et al. (1987) and Zakut et al. (1989), who showed no hybridization of BCHE cDNA to chromosome 2 .

Additional evidence supporting the interpretation that the $\mathrm{BChE}$ component of $\mathrm{C} 5$ originates from the same $\mathrm{BCHE}$ locus as the major $\mathrm{BChE}$ enzyme comes from the work of Arpagaus et al. (1990) and Masson et al. (1990). Arpagaus et al. (1990) isolated the $\mathrm{BCHE}$ gene and reported that the human genome contains a single copy of the $\mathrm{BCHE}$ gene. This conclusion can be challenged with the argument that Arpagaus et al. examined DNA from three individuals and would therefore have missed a second BCHE gene that existed in only a small percentage of the population. Masson et al. (1990) examined the possibility that a small percentage of the population might carry two BCHE genes. The most likely section of the population that might carry a second gene was the group that carried the C5 component, a group that includes $10 \%$ of Caucasians (Robson and Harris, 1966). Therefore, Masson et al. (1990) prepared Southern blots from total genomic DNA isolated from three people with the C5 phenotype. Hybridization results revealed that people with the $\mathrm{C} 5$ phenotype had a single copy of the $\mathrm{BCHE}$ gene and that this $\mathrm{BCHE}$ gene was indistinguishable from the $\mathrm{BCHE}$ gene that is present in people lacking $\mathrm{C} 5$. The argument that can be raised against this conclusion is that hybridization conditions were too stringent to detect a second $\mathrm{BCHE}$ locus that might be less than $70 \%$ identical with the major $\mathrm{BCHE}$ locus.

The interpretation we favor is that $\mathrm{C} 5$ is a hybrid protein encoded by the BCHE gene on chromosome 3 bands $q 21-q 26$ and an unidentified gene on chromosome 2 . A recent example of the ability of serum BChE to combine with a foreign protein comes from the work of Masson (1989), who found that the electrophoretic band termed $\mathrm{C} 2$ is a disulfide-linked complex between one $\mathrm{BChE}$ subunit and one albumin molecule. An alternative interpretation for C5 was presented by Soreq et al. (1987), who suggested that CHE2 codes for a protein which is similar to that encoded by the $\mathrm{BCHE}$ locus and that $\mathrm{CHE} 2$ maps to chromosome 16. 
The question of the number of BCHE genes is very important to the Human Genome Mapping and Sequencing project. Single-copy DNA sequences (that occur only once in the genome) that can be easily recovered by PCR are proposed as the landmarks that define position on the physical map (Olson et al., 1989). In our view BCHE can be one of these sequence-tagged sites (STS) for the long arm of chromosome 3. To date we have recovered BCHE sequences by PCR from total genomic DNA of approximately 100 individuals with results that are completely consistent with the existence of a single functional $\mathrm{BCHE}$ gene. Though BCHE cDNA hybridized to two regions on chromosome 3 (Zakut et al., 1989) and one region on chromosome 16. (Soreq et al., 1987; Zakut et al., 1989), these additional regions do not interfere with amplification of the $\mathrm{BCHE}$ gene by PCR.

The possibility exists that the additional loci that hybridize to BCHE cDNA (Soreq et al., 1987; Zakut et al., 1989) are genes homologous to the major form of BCHE. The homology might be too low to allow hybridization to PCR oligonucleotides, and too low to hybridize to cDNA on Southern blots, but high enough to be responsive to the conditions used in hybridization to chromosomes. If this is the case, then the question becomes one of definition as to what percentage homology classifies a gene as $\mathrm{BCHE}$. This question was raised at the third CHE meeting, where it was concluded that sequence information from many more animals was needed before it would be clear what distinguished butyrylcholinesterase from several related esterases including acetylcholinesterase and carboxylesterases.

\section{ACKNOWLEDGMENTS}

We thank Professor Phyllis J. McAlpine, Chair of the Human Gene Mapping Nomenclature Committee, for her advice regarding nomenclature. Blood samples from rare genetic variants were obtained through the dedicated efforts of anesthesiologists, Dr. Harold Lightstone, Dr. H. Rubinstein, and Dr. Abraham F. L. van der Spek. Dr. Karen James provided blood samples from 50 members of one pedigree. This work was supported by NIH Grant GM27028 (to B.N.L.) and US Army Medical Research and Development Command DAMD17-89-C9022 (to O.L.).

\section{REFERENCES}

Arpagaus, M., Kott, M., Vatsis, K. P., Bartels, C. F., La Du, B. N., and Lockridge, O. (1990). Structure of the gene for human butyrylcholinesterase. Evidence for a single copy. Biochemistry 29:124-131.

Bartels, C. F., van der Spek, A., Lockridge, O., and La Du, B. N. (1989). A polymorphism (K variant?) of human serum cholinesterase at nucleotide 1615, coding for Ala/Thr 539. FASEB J. 3:A741.

Delbruck, A., and Henkel, E. (1979). A rare genetically determined variant of pseudocholinesterase in two German families with high plasma enzyme activity. Eur. J. Biochem. 99:65-69. 
Eckerson, H. W., Oseroff, A., Lockridge, O., and La Du, B. N. (1983). Immunological comparison of the usual and atypical human serum cholinesterase phenotypes. Biochem. Genet. 21:93-108.

Eiberg, H., Nielsen, L. S., Klausen, J., Dahlen, M., Kristensen, M., Bisgaard, M. L., Moller, N., and Mohr, J. (1989). Linkage between serum cholinesterase 2 (CHE2) and $\gamma$-crystallin gene cluster (CRYG): Assignment to chromosome 2. Clin Genet. 35:313-321.

Evans, R. T., and Wardell, J. (1984). On the identification and frequency of the $\mathbf{J}$ and $\mathbf{K}$ cholinesterase phenotypes in a Caucasian population. J. Med. Genet. 21:99-102.

Garry, P. J., Dietz, A. A., Lubrano, T., Ford, P. C., James, K., and Rubinstein, H. M. (1976). New allele at cholinesterase locus 1. J. Med Genet. 13: 38-42.

Harris, H., and Whittaker, M. (1961). Differential inhibition of human serum cholinesterase with fluoride. Recognition of two new phenotypes. Nature Lond. 191:496-498.

Harris, H., Robson, E. B., Glen-Bott, A. M, and Thornton, J. A. (1963). Evidence for non-allelism between genes affecting human serum cholinesterase. Nature 200:1185-1187.

Kalow, W. (1962). Pharmacogenetics, Heredity and the Response to Drugs. W. B. Saunders, Philadelphia, pp. 69-93.

Kalow, W., and Genest, K. (1957). A method for the detection of atypical forms of human cholinesterase; Determination of dibucaine numbers. Can. J. Biochem. Physiol. 35:339-346.

Kalow, W., and Gunn, D. R. (1959). Some statistical data on atypical cholinesterase of human serum. Ann. Hum. Genet. 23:239-250.

Kalow, W., and Lindsay, H. A. (1955). A comparison of optical and manometric methods for the assay of human serum cholinesterase. Can. J. Biochem. Physiol. 33:568-574.

Kalow, W., and Staron, N. (1957). On distribution and inheritance of atypical forms of human serum cholinesterase, as indicated by dibucaine numbers. Can. J. Biochem. Physiol. 35:1305-1320.

Krause, A., Lane, A. B., and Jenkins, T. (1988). A new high activity plasma cholinesterase variant. J. Med. Genet. 25:677-681.

La Du, B. N., Bartels, C. F., Nogueira, C. P., Hajra, A., Lightstone, H., van der Spek, A., and Lockridge, O. (1990). Phenotypic and molecular biological analysis of human serum cholinesterase variants. Clin. Biochem. 23:423-431.

Liddell, J., Lehmann, H., and Silk, E. (1962). A "silent" pseudocholinesterase gene. Nature (Lond.) 193:561-562.

Lockridge, O. (1990). Genetic variants of human serum cholinesterase influence metabolism of the muscle relaxant succinylcholine. Pharmacol. Ther. 47:35-60.

Lockridge, O., and La Du, B. N. (1978). Comparison of atypical and usual human serum cholinesterase: Purification, number of active sites, substrate affinity, and turnover number. $J$. Biol. Chem. 253:361-366.

Lovrien, E. W., Magenis, R. E., Rivas, M. L., Lamvik, N., Rowe, S., Wood, J., and Hemmerling, J. (1978). Serum cholinesterase (E2) linkage analysis: Possible evidence for localization to chromosome 16. Cytogenet. Cell Genet. 22:324-325.

Marazita, M. L., Keats, B. J. B., Spence, M. A., Sparkes, R. S., Field, L. L., Sparkes, M. C., and Crist, M. (1989). Mapping studies of the serum cholinesterase-2 locus (CHE2). Hum. Genet. 83:139-144.

Masson, P. (1989). A naturally-occurring molecular form of human plasma cholinesterase is an albumin conjugate. Biochim. Biophys. Acta 988:258-266.

Masson, P., Chatonnet, A., and Lockridge, O. (1990). Evidence for a single butyrylcholinesterase gene in individuals carrying the $\mathrm{C} 5$ plasma cholinesterase variant (CHE2). FEBS Lett. 262:115-118.

McGuire, M. C., Nogueira, C. P., Bartels, C. F., Lightstone, H., Hajra, A., van der Spek, A. F. L., Lockridge, O., and La Du, B. N. (1989). Identification of the structural mutation responsible for the dibucaine-resistant (atypical) variant form of human serum cholinesterase. Proc. Natl. Acad. Sci. USA 86:953-957.

Neitlich, H. W. (1966). Increased plasma cholinesterase activity and succinylcholine resistance: A genetic variant. J. Clin. Invest. 45:380-387.

Nogueira, C. P., McGuire, M. C., Graeser, C., Bartels, C. F., Arpagaus, M., van der Spek, A. F. L., Lightstone, H., Lockridge, O., and La Du, B. N. (1990). Identification of a frameshift mutation responsible for the silent phenotype of human serum cholinesterase, Gly 117, (GGT $\rightarrow$ GGAG). Am. J. Hum. Genet. 46:934-942.

Olson, M., Hood, L., Cantor, C., and Botstein, D. (1989). A common language for physical mapping of the human genome. Science 245:1434-1435.

Robson, E. B., and Harris, H. (1966). Further data on the incidence and genetics of the serum cholinesterase phenotype C5+. Ann. Hum. Genet. Lond. 29:403-408.

Robson, E. B., Sutherland, I., and Harris, H. (1966). Evidence for linkage between the transferrin locus (Tf) and the serum cholinesterase locus (El) in man. Ann. Hum. Genet. Lond. 29:325-332. 
Rubinstein, H. M., Dietz, A. A., Hodges, L. K., Lubrano, T., and Czebotar, V. (1970). Silent cholinesterase gene: Variations in the properties of serum enzyme in apparent homozygotes. $J$. Clin. Invest. 49:479-486.

Rubinstein, H. M., Dietz, A. A., and Lubrano, T. (1978). $\mathrm{E}_{1}^{\mathrm{k}}$, another quantitative variant at cholinesterase locus 1. J. Med. Genet. 15:27-29.

Savarese, J. J., Ali, H. H., Basta, S. J., Embree, P. B., Scott, R. P. F., Sunder, N., Weakly, J. N., Wastila, W. B., and El-Sayad, H. A. (1988). The clinical neuromuscular pharmacology of mivacurium chloride (BW B1090U). A short-acting nondepolarizing ester neuromuscular blocking drug. Anesthesiology 68:723-732.

Scott, E. M., and Powers, R. F. (1974). Properties of the C5 variant form of human serum cholineserase. Am. J. Hum. Genet. 26:189-194.

Shows, T. B., McAlpine, P. J., Boucheix, C., Collins, F. S., Conneally, P. M., Frezal, J., Gershowitz, H., Goodfellow, P. N., Hall, J. G., Issitt, P., Jones, C. A., Knowles, B. B., Lewis, M., McKusick, V. A., Meisler, M., Morton, N. E., Rubinstein, P., Schanfield, M. S., Schmickel, R. D., Skolnick, M. H., Spence, M. A., Sutherland, G. R., Traver, M., Van Cong, N., and Willard, H. F., (1987). Guidelines for human gene nomenclature. An International System for Human Gene Nomenclature (ISGN, 1987). Cytogenet. Cell Genet. 46:11-28.

Simpson, N. E., and Elliott, C. R. (1981). Cholinesterase Newfoundland: A new succinylcholinesensitive variant of cholinesterase at locu 1. Am. J. Hum. Genet. 33:366-374.

Soreq, H., Zamir, R., Zevin-Sonkin, D., and Zakut, H. (1987). Human cholinesterase genes localized by hybridization to chromosomes 3 and 16. Hum. Genet. 77:325-328.

Sparkes, R. S., Field, L. L., Sparkes, M. C., Crist, M., Spence, M. A., James, K., and Garry, P. J. (1984). Genetic linkage studies of transferrin, pseudocholinesterase, and chromosome 1 loci. Hum. Hered. 34:96-100.

Tunek, A., and Svensson, L. A. (1988). Bambuterol, a carbamate ester prodrug of terbutaline, as inhibitor of cholinesterases in human blood. Drug Metab. Dispos. 16:759-764.

Viby-Mogensen, J. (1983). Cholinesterase and succinylcholine. Danish Med. Bull. 30:129-150.

Whittaker, M. (1986). Cholinesterase. Monograph in Human Genetics, Vol. 11, Karger, Basel, pp. 1-134.

Whittaker, M., and Britten, J. J. (1985). Plasma cholinesterase variants: Family studies of the $E_{1}^{\mathbf{k}}$ gene. Hum. Hered. 35:364-368.

Whittaker, M., and Britten, J. J. (1987). $\mathrm{E}_{1}^{\mathrm{h}}$, a new allele at cholinesterase locus 1. Hum. Hered. 37:54-58.

Whittaker, M., and Britten, J. J. (1988). Recognition of two new phenotypes segregating the $E_{1}^{k}$ allele from plasma cholinesterase. Hum. Hered. 38:233-239.

Yang, F., Lum, J. B., McGill, J. R., Moore, C. M., Naylor, S. L., Van Bragt, P. H., Baldwin, W. D., and Bowman, B. H. (1984). Human transferrin: cDNA characterization and chromosomal localization. Proc. Natl. Acad. Sci. USA 81:2752-2756.

Yoshida, A., and Motulsky, A. G. (1969). A Pseudocholinesterase variant (E Cynthiana) associated with elevated plasma enzyme activity. Am. J. Hum. Genet. 21:486-498.

Zakut, H., Zamir, R., Sindel, L., and Soreq, H. (1989). Gene mapping on chorionic villi chromosomes by hybridization in situ: Localization of cholinesterase cDNA binding sites to chromosomes 3q21, 3a26-ter and 16q21. Hum. Reprod. 4:941-946. 